Spring 1987

\title{
International Business Education in the AACSB Schools
}

Ivan R. Vernon

Cleveland State University, I.VERNON@csuohio.edu

John Thanopoulos

University of Akron Main Campus

Follow this and additional works at: https://engagedscholarship.csuohio.edu/busmarkt_facpub

Part of the International Business Commons, and the Other Education Commons

How does access to this work benefit you? Let us know!

Publisher's Statement

(c) 1987 Palgrave Macmillan

\section{Original Citation}

Thanopoulos, J., Vernon, I. R. (1987). International Business Education in the AACSB Schools. Journal of International Business Studies, 18, 1, 91-98. doi: 10.1057/palgrave.jibs.8490402

\section{Repository Citation}

Vernon, Ivan R. and Thanopoulos, John, "International Business Education in the AACSB Schools" (1987).

Marketing. 49.

https://engagedscholarship.csuohio.edu/busmarkt_facpub/49

This Article is brought to you for free and open access by the Browse Business Faculty Books and Publications by Topic at EngagedScholarship@CSU. It has been accepted for inclusion in Marketing by an authorized administrator of EngagedScholarship@CSU. For more information, please contact library.es@csuohio.edu. 


\title{
INTERNATIONAL BUSINESS EDUCATION IN THE AACSB SCHOOLS
}

\author{
Ivan R. Vernon, Cleveland State University \\ John Thanopoulos
}

This article was originally published in:

Thanopoulos, J., Vernon, I. R. (1987). International Business Education in the AACSB Schools. Journal of International Business Studies, 18, 1, 91-98.

Post-print standardized by MSL Academic Endeavors, the imprint of the Michael Schwartz Library at Cleveland State University, 2012

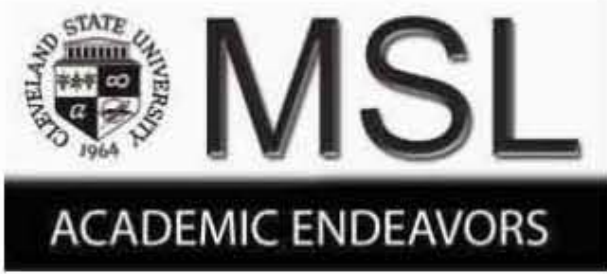




\title{
INTERNATIONAL BUSINESS EDUCATION IN THE AACSB SCHOOLS
}

\author{
John Thanopoulos* \\ The University of Akron \\ Ivan R. Vernon** \\ Cleveland State University
}

\begin{abstract}
The study analyzes the responses of 411 AACSB member schools with respect to their offerings in international business. The findings of this study are that international business material is often incorporated into functional courses, and that among AACSB schools the accredited ones are not significantly different from the nonaccredited ones in terms of curricula composition.
\end{abstract}

In 1980 the president of the National Association of Manufacturers stated that "America no longer faces a question of whether it has lost its international competitive edge, but rather why and what can be done about it" (Winchester 1980). During that year the U.S. trade deficit reached 33.6 billion dollars (U.S. I.T.C. Operation 1982). Between 1980 and 1985 the deficit quadrupled, and there are only weak signs at best that the deficit will diminish during 1986 and 1987. Moreover, in 1984 the combined value of U.S. trade in goods and services approached the one trillion dollar mark (Hervey 1985).

All national economies, including the American economy, depend on global markets, material sources, and production means. This dependence creates problems in such areas as domestic employment and balance of payments. It also offers such advantages as cheaper goods and wider consumer choices. Achieving an appropriate balance of the problems and advantages of international trade requires study of comparative advantages and careful estimation of the efforts needed to increase national competitiveness. Several recent studies have suggested the need to improve the level of international business education offered to U.S. college graduates in order to improve the performance of American executives with international business responsibilities (Excellence Report 1982; Critical Needs 1983; Global Competition 1985).

* John Thanopoulos (B.A., M.S., Ph.D.) is Associate Professor of Marketing and Director of International Business at the University of Akron. His previous publications are in the areas of international business, marketing, economics, and statistics.

** Ivan R. Vernon (B.A., M.B.A., D.B.A.) is Associate Professor of Marketing at Cleveland State University. His interests and previous publications are in the areas of international marketing and finance.

Received: December 1985; Revised: April \& May 1986; Accepted: July 1986. 


\section{INTERNATIONAL BUSINESS EDUCATION IN THE AACSB SCHOOLS}

The American Assembly of Collegiate Schools of Business (AACSB) was among the first to promote the internationalization of business education. Professor Lee Nehrt (1981) reported that AACSB had some awareness of this need as early as 1959, the year the Academy of International Business (AIB) was founded. Furthermore, he reported that the first international business courses were offered in the mid-1950's. Following its initial awareness of the need for internationalization, AACSB proceeded to prepare appropriate guidelines and sponsor regular seminars to educate its members of the complexities of international topics (International 1977; Internationalization 1979). Recent reports indicate that U.S. business schools actively revise their offerings in order to meet the changing needs of U.S. firms (Swartz 1985), although "most managers acquire international expertise through business experiences" (Kobrin 1984).

The purpose of the present work is to investigate the international business curricula offered in the AACSB member schools. The study is based on an analysis of data gathered from 411 AACSB member schools during Spring, 1985 (Thanopoulos 1986). The next section reports on research procedural matters, and is followed by a section of findings.

\section{PROCEDURAL MATTERS AND RESEARCH METHODOLOGY}

Due to budgetary constraints this study included only the AACSB member schools. AACSB member schools include all the business programs actually accredited by AACSB at the bachelors and/or masters levels. While AACSB membership does not imply accreditation, AACSB member schools, whether accredited or not, provide a logical and convenient sample base. The member schools are broadly representative of North America four-year degree-granting institutions and include as well a number of non-North American programs.

Six hundred and ninety-four (694) member institutions were identified from the AACSB Directory. The surveys were addressed to the deans of each of these institutions. The letters requested that the survey instrument be forwarded to the faculty member most directly responsible for international business education. A follow-up reminder was sent to nonrespondents, and four-hundred and eleven (411) usable answers, approximately $59.2 \%$ of the sampling frame, were returned prior to the established cutoff date.

Data gathered describe undergraduate, masters, and doctoral programs, and include the variables listed in Table 1 .

The information received was on a nominal scale (yes/no) for the variables MAJIB, MINIB, MACIB, MICIB, LAREQ, and LAREC. For the rest of the variables the respondents indicated the number of sections of the particular course offered during 1984-85; if the course was listed in the university's bulletin but was not regularly offered, the respondents were instructed to so indicate. Other variables in this survey included: size of student body in 1984-85 and 198182 , number of faculty members teaching and/or researching international business topics, and practices in administering the international business program (example: existence of a specific department of international business). Data analysis is based on tests of homogeneity, Z-tests (Cangelosi 1983), and stepwise procedures (SAS 1982). 


\section{INTERNATIONAL BUSINESS EDUCATION IN THE AACSB SCHOOLS}

TABLE 1

Variable Definitions

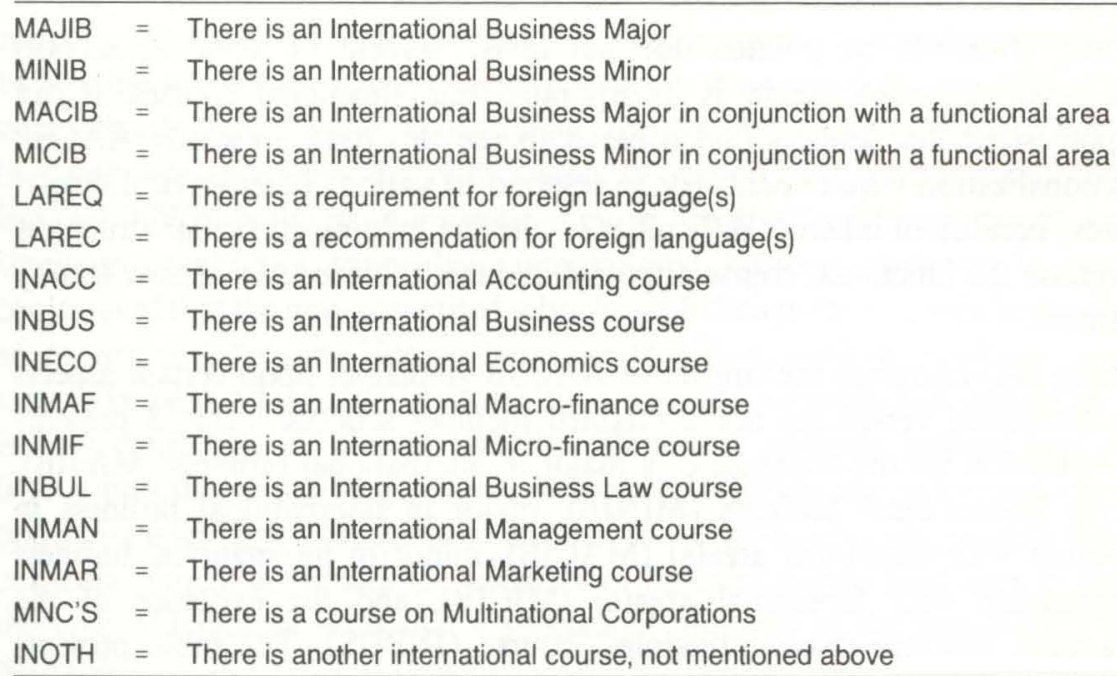

\section{FINDINGS}

Table 2 provides comparisons between current ways of handling international business programs and the practices followed five years earlier. The data show that International Business Departments exist in the same absolute number as in the past, that international business material is increasingly incorporated into functional courses, and that functionally-oriented faculty members, not specializing in international business areas, continue to teach the international business courses in most of the responding schools.

TABLE 2

Details about the International Business Programs

\begin{tabular}{lcc}
\hline & $\begin{array}{c}1980 \\
\text { Grosse \& } \\
\text { Perritt }\end{array}$ & $\begin{array}{c}1985 \\
\text { Present } \\
\text { Study }\end{array}$ \\
\hline $\begin{array}{l}\text { The International Business Program is housed in an International } \\
\text { Business Department }\end{array}$ & $7 \%$ & $5 \%$ \\
The International Business Program is housed in another Department & $19 \%$ & $26 \%$ \\
International Business material is incorporated in functional courses & $31 \%$ & $67 \%$ \\
Functional faculty members teach specific International Business & $41 \%$ & $62 \%$ \\
courses & $2 \%$ & \\
Other & 227 & 411 (*) \\
\hline Total responding schools
\end{tabular}

Note: $\left(^{*}\right)$ Multiple responses are possible for the 1985 survey. Thus, the reader is advised to avoid direct comparisons between the two studies. Source: 1980 Survey (page 188) and present study.

This data pattern is consistent with another finding indicating that, on average, at least 1.92 professors per school have a primary teaching interest in international business topics, whereas if the total number of faculty members having international business orientation is assumed, this average increases to 4.16 . Thus, 


\section{INTERNATIONAL BUSINESS EDUCATION IN THE AACSB SCHOOLS}

the lack of specialized faculty members may explain why (as revealed in Table 2) international business material is still incorporated into the functional courses in two-thirds of the AACSB schools.

Moreover, it should be pointed out that in 67 percent of reporting schools international business material is incorporated into functional courses. It can be hypothesized that schools find it easier to use this route to satisfy AACSB internationalization requirements (or to respond to various other environmental pressures) because of inherent difficulties in altering existing curricular structures and because the functional course approach reduces the necessity of new faculty recruitment.

The study also examines the impact of AACSB guidelines upon certain aspects of the accredited versus the non-accredited member schools. Table 3 presents this information for the existence of a major in international business (MAJIB), minor in international business (MINIB), major in international business in conjunction with functional area(s) (MACIB), minor in international business in conjunction with functional area(s) (MICIB), and the existence of the international business (basic/principles) course (INBUS). The table presents information separately for undergraduate and masters programs.

TABLE 3

International Business Programs:

Totals of AACSB Accredited Versus

Non-Accredited Member Schools

\begin{tabular}{lrr}
\hline Variable $^{*}$ & Accredited & $\begin{array}{c}\text { Non- } \\
\text { Accredited }\end{array}$ \\
\hline Undergraduate & & \\
\hline MAJIB & 35 & 38 \\
MINIB & 25 & 31 \\
MACIB & 14 & 15 \\
MICIB & 12 & 18 \\
INBUS & 79 & 97 \\
Number of Schools & 147 & 181 \\
\hline Masters & & 36 \\
\hline MAJIB & 36 & 21 \\
MINIB & 17 & 9 \\
MACIB & 10 & 10 \\
MICIB & 10 & 131 \\
INBUS & 54 & \\
Number of Schools & 117 & 37 \\
\hline
\end{tabular}

*See Table I for definitions of variables.

Individual Z-tests for two population proportions and for each of the variables in Table 3 were run to test the hypothesis of no difference between accredited and non-accredited schools $(a=0.05)$. The findings of this part of the study indicate that no significant differences exist between the accredited and the non-accredited members of AACSB with respect to offering of majors, minors, and the basic course in international business. 


\section{INTERNATIONAL BUSINESS EDUCATION IN THE AACSB SCHOOLS}

However, the analysis of foreign language requirements yielded an interesting result. Of the responding non-accredited AACSB member schools $21 \%$ indicated that they "require" foreign language skills of their international business students, and an additional $19 \%$ indicated that they "recommend" foreign languages. Only $14 \%$ of the accredited schools "require" foreign language skills, but $26 \%$ of these same schools "recommend" foreign languages for their students. Combining these two response categories for both classes of respondents, one is struck by the fact that $40 \%$ of both sets of institutions either "require" or "recommend" foreign language capabilities from their international business students. It may be conjectured that the non-accredited schools, with their greater curricular flexibility, are more able to "require" foreign languages than those institutions whose curricula may have been adjusted to conform to established accreditation standards. This is only conjecture, of course, and the differential response pattern may result from some other underlying factor or factors. Nevertheless, the differential response pattern justifies raising the question whether the necessity of conforming to AACSB curricula standards reduces the capacity of business degree programs to require the type of language skills that a substantial minority of the respondents deem desirable.

In addition, the study identified the faculty members having a primary interest in teaching international courses. Table 4 presents this information for each of the international courses together with the number of schools offering each course.

TABLE 4

Major Courses in International Business Education and Number of Professors with Primary Teaching Interest in International Business Courses

\begin{tabular}{lcccc}
\hline Course $\dagger$ & \multicolumn{2}{c}{$\begin{array}{c}\text { (Number of Schools Offering Course) } \\
\text { Masters }\end{array}$} & $\begin{array}{c}\text { Number of } \\
\text { Doctoral }\end{array}$ & $\begin{array}{r}\text { Numbersors } \\
\text { Professors }\end{array}$ \\
\hline INACC & 67 & 56 & 6 & 34 \\
INBUS & 176 & 121 & 12 & 124 \\
INECO & 201 & 113 & 19 & 81 \\
INMAF & 133 & 113 & 17 & $136^{*}$ \\
INMIF & 97 & 96 & 11 & $136^{*}$ \\
INBUL & 36 & 45 & 3 & 9 \\
INMAN & 112 & 108 & 14 & 103 \\
INMAR & 222 & 150 & 16 & 144 \\
MNC'S & 46 & 54 & 7 & 11 \\
INOTH & 65 & 60 & 10 & 145 \\
\hline TOTALS & 328 & 248 & 43 & 787 \\
\hline
\end{tabular}

"No information was gathered enabling the authors to differentiate between the professors teaching macro-finance versus the micro-finance courses.

†See Table 1 for definitions of variables.

Note: With respect to the professors, Table 4 presents data derived from 164 schools and only for those who were clearly associated with the above courses. Thus, the table understates the actual number of professors who primarily teach the above areas. Example: A professor's primary teaching area is international marketing, but the respondent mentions only "marketing," assuming an automatic classification under international. The study, however, covered 411 schools and 1,711 professors. 


\section{INTERNATIONAL BUSINESS EDUCATION IN THE AACSB SCHOOLS}

Finally, Table 5 presents cross-tabulations of level of study (undergraduate, masters, and doctoral) against "standardized" courses in international business education and other variables of concern. A homogeneity test of course offerings and level of study at the different institutions leads to the rejection of the hypothesis of no difference in international business courses configuration for each level of study $(a<0.05)$. This finding indicates that the responding institutions have a significantly different composition in their offerings of international business courses.

TABLE 5

Major Variables of the International Business Education and Levels of Study

\begin{tabular}{lrrrrrr}
\hline & \multicolumn{2}{c}{ Undergraduate } & \multicolumn{2}{c}{ Masters } & \multicolumn{2}{c}{ Doctoral } \\
Variable & Total & Percent & Total & Percent & Total & Percent \\
\hline INACC & 67 & 20 & 56 & 23 & 6 & 14 \\
INBUS & 176 & 54 & 121 & 49 & 12 & 28 \\
INECO & 201 & 61 & 113 & 46 & 19 & 44 \\
INMAF & 133 & 41 & 113 & 46 & 17 & 40 \\
INMIF & 97 & 30 & 96 & 39 & 11 & 26 \\
INBUL & 36 & 11 & 45 & 18 & 3 & 7 \\
INMAN & 112 & 34 & 108 & 44 & 14 & 33 \\
INMAR & 222 & 68 & 150 & 61 & 16 & 37 \\
MNC'S & 46 & 14 & 54 & 22 & 7 & 16 \\
INOTH & 65 & 20 & 60 & 24 & 10 & 23 \\
& & & & & & \\
MAJIB & 73 & 22 & 72 & 29 & 21 & 49 \\
MINIB & 56 & 17 & 37 & 15 & 16 & 37 \\
MACIB & 29 & 9 & 19 & 8 & 3 & 7 \\
MICIB & 30 & 9 & 20 & 8 & 8 & 19 \\
LAREQ & 73 & 22 & 25 & 10 & 5 & 12 \\
LAREC & 71 & 22 & 33 & 13 & 7 & 16 \\
\hline TOTALS & 328 & 100 & 248 & 100 & 43 & 100 \\
\hline
\end{tabular}

*See Table 1 for definitions of variables.

The international marketing course is regularly taught in $68 \%$ of the undergraduate and $61 \%$ of the masters programs. In order to investigate the reasons for its appeal, the frequency with which this course is taught was regressed on a series of graduate and undergraduate variables, including other courses regularly taught, courses not regularly taught, number of faculty members interested in international business, and student body size and growth. It appears that the single variable that most closely correlates with the frequency with which the international marketing course is taught is "other international business courses regularly offered" (actually those mentioned in this study, i.e., a proxy of a well-developed international business program). Thus, it may be said that this course covaries with the existence of a well-developed international business program. When the number of sections of other international business courses regularly offered is regressed against the number of sections of international marketing, an $r^{2}=.4658$ is found at the undergraduate level and .8255 at the graduate (collapsed information between masters and doctoral programs). 


\section{INTERNATIONAL BUSINESS EDUCATION IN THE AACSB SCHOOLS}

In addition, from a theoretical perspective, the international marketing course better satisfies parsimony concerns. Among all tested international courses, it is the only one that achieves this $r^{2}$ level with a single independent variable. In contrast, the international accounting course, although taught in one out of every five AACSB member schools, presents an unexplainable low $r^{2}$ when regressed against the same variables. At the undergraduate level it presents an $r^{2}=.1208$ when regressed with only undergraduate variables and .2010 when graduate variables enter the model. At the graduate level the international accounting course presents no better than $r^{2}=.0971$ when standard stepwise procedures are employed.

Even more interesting results are derived from the international finance courses. For example, the international macro-finance course at the graduate level, when regressed with eight dependent variables, presents an $r^{2}=.8502$, whereas the international micro-finance course shows a low .1096. However, the picture reverses at the undergraduate level, where the international micro-finance course presents a better $r^{2}(.5427)$ than the international macro-finance (.3992). It should be mentioned that the collected data does not allow for causation inferences, especially since similar analyses, by design, include autocorrelation elements that reduce the validity of such conclusions.

\section{SUMMARY AND SUGGESTIONS FOR FURTHER RESEARCH}

Experts have indicated the need to increase the international competitiveness of American business. Based on this study, it can be concluded that some favorable developments have occurred in the internationalization of business curricula at AACSB member schools. It appears also, that a significant number of professors teach and conduct research in international business. Concurrently, in most cases functional faculty members continue to teach the majority of specific international business courses. Two more important observations are worth noting. First, international business material is often incorporated into functional courses; second, among AACSB schools the accredited ones are not significantly different from the non-accredited ones in terms of progress in the internationalization of their curricula.

For future research direction, it should be recognized that little data exists to compare the progress of AACSB accredited and non-accredited schools in internationalizing the business curricula. Also, the possibility that accreditation requirements may in some respect retard rather than enhance the internationalization of business education is indeed disturbing and points to the need for further research.

However, now is the time to prescribe future direction. The international business courses offered do not follow a homogeneous structure among the institutions teaching them. These institutions have developed their international business program structure from within, often depending only on their own resource availability and the course demand. It is suggested that specific analysis of this nation's needs in international business education be undertaken in order to develop an exact delineation of future offerings and program structures. 


\section{INTERNATIONAL BUSINESS EDUCATION IN THE AACSB SCHOOLS}

Educational institutions should structure their international business offerings on the basis of the country's specific needs in the global marketplace and not on the basis of domestic convenience or readily available resources. Thus, the authors believe that studies should be undertaken immediately to develop longrange strategies to improve American international business education and that the findings and recommendations of these studies should be directed to individuals and institutions capable of influencing decisions and policies affecting national educational policy. The American educational institutions need specific guidelines and often encouragement in this process.

\section{REFERENCES}

America's competitive challenge: The need for a national response. 1983. Washington: Business-Higher Education Forum, April.

Cangelosi, Vincent E., Phillip H. Taylor, \& Philip F. Rice. 1983. Basic statistics: A real world approach (3rd ed). St. Paul, MN: West Publishing Company.

Critical needs in international education: Recommendations for action. 1983. Washington: National Advisory Board on International Education Programs, December.

Daniels, John D. \& Lee H. Radebaugh. 1974. International business curriculum survey. Cleveland: Academy of International Business.

The excellence report: Using it to improve your schools. 1983. Arlington, VA: American Association of School Administrators 3-12. (Contains the report to the President. 1982. A nation at risk: The imperative for educational reform).

Global competition: The new reality. 1985. Report of the President's Commission on Industrial Competitiveness, Vol 1. Washington: Government Printing Office, January.

Grosse, Robert \& Gerald W. Perritt. 1980. International business curricula: A global survey. Cleveland: Academy of International Business.

Hervey, Jack L. 1985. Broadened Awareness of the International Sector. International Letter. Chicago: Federal Reserve Bank of Chicago, May l: 1-3.

International Education Project. 1977. Business and international education. Washington: American Council on Education, May.

The internationalization of the business school curriculum. 1979 Proceedings. St. Louis: AACSB, March.

Kobrin, Stephen J. 1984. International expertise in American business: How to learn to play with the kids on the street. New York: Institute of International Education, 37.

Nehrt, Lee C. 1981. Case studies of internationalization of business school curriculum. St. Louis: AACSB, October.

SAS user's guide: Statistics. 1982. Cary, NC: SAS Institute, 404-410.

Swartz, Steve. 1985. Business schools revise programs to meet firms changing needs. The Wall Street Journal, March 28, 33.

Thanopoulos, John (with the assistance of J. W. Leonard). 1986. International business curricula: A global survey. Cleveland: Academy of International Business.

U. S. International Trade Commission. 1982. Operation of the trade agreements program. 34th Report. U.S.ITC Publication 1414. Washington: Government Printing Office, 8.

Winchester, Mark B., ed. 1980. The international essays for business decision makers, Vol. 5. Houston: Center for International Business and AMACOM, i. 